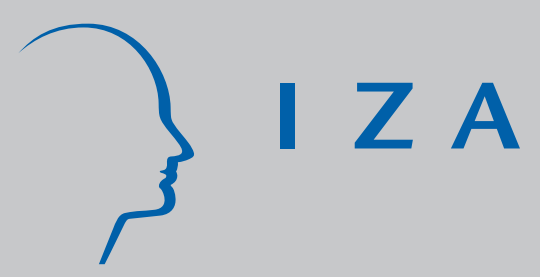

IZA DP No. 348

Can Vocational Education Improve the Wages of Minorities and Disadvantaged Groups?

The Case of Israel

Shoshana Neuman

Adrian Ziderman

August 2001 


\title{
Can Vocational Education Improve the Wages of Minorities and Disadvantaged Groups? The Case of Israel
}

\author{
Shoshana Neuman \\ Department of Economics, Bar-Ilan University and IZA, Bonn \\ Adrian Ziderman \\ Department of Economics, Bar-llan University
}

Discussion Paper No. 348
August 2001

\author{
IZA \\ P.O. Box 7240 \\ D-53072 Bonn \\ Germany \\ Tel.: +49-228-3894-0 \\ Fax: +49-228-3894-210 \\ Email: iza@iza.org
}

This Discussion Paper is issued within the framework of IZA's research area The Future of Work. Any opinions expressed here are those of the author(s) and not those of the institute. Research disseminated by IZA may include views on policy, but the institute itself takes no institutional policy positions.

The Institute for the Study of Labor (IZA) in Bonn is a local and virtual international research center and a place of communication between science, politics and business. IZA is an independent, nonprofit limited liability company (Gesellschaft mit beschränkter Haftung) supported by the Deutsche Post AG. The center is associated with the University of Bonn and offers a stimulating research environment through its research networks, research support, and visitors and doctoral programs. IZA engages in (i) original and internationally competitive research in all fields of labor economics, (ii) development of policy concepts, and (iii) dissemination of research results and concepts to the interested public. The current research program deals with (1) mobility and flexibility of labor markets, (2) internationalization of labor markets and European integration, (3) the welfare state and labor markets, (4) labor markets in transition, (5) the future of work, (6) project evaluation and (7) general labor economics.

IZA Discussion Papers often represent preliminary work and are circulated to encourage discussion. Citation of such a paper should account for its provisional character. 
IZA Discussion Paper No. 348

August 2001

\section{ABSTRACT}

\section{Can Vocational Education Improve the Wages of Minorities and Disadvantaged Groups? The Case of Israel *}

There is a considerable empirical literature which compares wage levels of workers who have studied at secondary vocational schools with wages of workers who took academic schooling. In general, vocational education does not lead to higher wages. However, in some countries where labor markets are characterized by employment growth, skill shortages and a good match between vocational skills and available jobs, the record of vocational schooling has been more positive. Israel constitutes a case in point. However, little attention has been given to examining the success of vocational education in raising the wages of various subsections of the labor force, in particular of minorities and disadvantaged groups. In this paper, we examine the efficacy of vocational education in raising the wage levels of four such groups: recent immigrants, Jews of Eastern origin, Israeli Arabs and females. The results are mixed, differing from group to group, thus justifying our approach of examining the impact of vocational schooling on finer breakdowns of the population of secondary school completers.

JEL Classification: I21, J15, J16, J21, J24, J31, J44, J61

Keywords: Wage differentials, human capital, gender, ethnicity, immigration, Arabs, vocational education.

Professor Shoshana Neuman

Department of Economics

Bar-Ilan University

52900 Ramat-Gan

ISRAEL

Tel: (972 3) 5318393

Fax: (972 3) 5353180

Email: neumans@mail.biu.ac.il

This paper forms part of a CEPR/TSER research project on Labour Demand, Education and the Dynamics of Social Exclusion, funded by the European Commission (award reference PL95-0685). 


\section{Introduction}

\section{Vocational Education and the Labor Market}

In many countries, the conventional wisdom of politicians and practical men of affairs, particularly in developing countries, is that pre-employment vocational education (VocEd) can provide a ready panacia for improving the lot of disadvantaged groups in society. Viewed as providing hand-on, practical skills, vocational schooling is frequently seen as a vehicle for improving the employability of the disadvantaged and augmenting expected wage levels. Indeed, in many countries, vocational education provision has been assigned dominantly social objectives. However, an extensive comparative, academic literature has developed over the last three decades which argues against this view. The major thrust of this accumulated research indicates that the wide scale provision of VocEd is both inefficient on economic grounds and unlikely to achieve social objectives defined in terms of assisting the disadvantaged. There are two main themes underlying this literature.

The first focuses on the need for the presence of a facilitating economic environment, in the absence of which vocational schooling in particular, as well as skills development programmes in general, are unlikely to be efficacious in meeting set social objectives. In many cases, jobs are not available nor good linkages forged between VocEd institutions and employers to ensure that courses provided are kept relevant to market needs. Without general employment growth and labor market demands for the particular skills provided by VocEd institutions, VocEd programmes are unlikely to make a contribution to such objectives as improving the prospects of poor youngsters gaining stable employment and augmented wages or of providing a path to wage employment for women. ${ }^{1}$ 
The second main theme relates to the cost effectiveness and economic efficacy of investments in pre-employment VocEd. This issue is partly concerned with the cost effectiveness of alternative modes of skills preparation: VocEd, pre-employment training institutes or employer-based training. However, most of this empirical literature has a different focus, addressing the question of the relative merits of VocEd and academic (general) secondary schooling, from a cost-benefit viewpoint. VocEd is more costly than academic schooling in almost all countries. ${ }^{2}$ Most studies comparing the labor market outcomes (in terms of earnings and employment) of VocEd graduates with those from lower cost general secondary schooling, report a lower rate of return on investment in VocEd. In many studies, the lower rates of return on VocEd result from comparatively low wages, particularly in low-income countries where VocEd capacity exceeds labor market demand and the external efficiency of VocEd is low. Other studies find that general secondary school and VocEd graduates earn about the same but the greater VocEd costs result in higher rates of return to general secondary schooling.

Recent research has qualified the established orthodoxy that argues strongly against VocEd on cost-benefit grounds. These studies have reported more favourable outcomes for VocEd. A series of studies for the USA (reviewed in Bishop 1989) focussed more closely than earlier studies on the type of jobs held by VocEd graduates and on the relationship between the VocEd specialty studied and subsequent employment. In contrast with the earlier work, these studies concluded that VocEd can confer labor market advantages in terms of participation, employment and wages for those VocEd graduates who work in 'matched' occupations, i.e. in jobs that are related to vocational courses followed at school. Those VocEd graduates working outside their field of specialty fare no better than workers who had studied in general tracks at secondary school. Consistent results are reported for Hong Kong (Chung 1990), China (Min and Tsang 1990), Brazil (Arriagada and Ziderman 1992), as well as for Israel (Neuman and Ziderman 1991 and 1999). A central factor accounting for the favourable Voced outcomes in these studies was the availability, or growth, of employment opportunities and the match between vocational skills and available jobs. 
Our earlier research on VocEd outcomes in Israel reported a wage differential, for VocEd graduates working in matched occupations, of over eight percent over nonmatched VocEd graduates and graduates of general secondary schools. However, our results related to secondary school completers as a whole; no separate estimates were made for particular disadvantaged or minority groups in Israel. Thus it is not known what contribution VocEd has made to improving the wellbeing of these groups. The central task of the present paper is to probe this issue. In the following four sections, we examine the interaction of acquired VocEd skills and success in the labor market for four disadvantaged groups. These are: recent immigrants (Section 2), Israeli Arab citizens (Section 3), Jews of Eastern or Oriental origin ('Sephardie' Jews - Section 4), and women (Section 5). A final Section 6 summarizes our results. These sections are preceded by a brief background account of the historical development, objectives and coverage of secondary vocational education in Israel.

\section{VocEd in Israel}

Table 1, showing the development of secondary schooling in Israel since statehood in 1948, highlights the expansion of VocEd, relative to academic schooling, over the ensuing half century. This growth of VocEd, from less than a fifth of all secondary school pupils to some 50 percent in the 1970 s, is to be seen largely as a response to fundamental problems facing the young state in its early years. An important role in explaining the growth and size of VocEd in Israel must be accorded to the desire to meet growing skilled manpower needs for defense and development (Glasman 1983). This was coupled with a national consensus that skills development should take place primarily within schooling rather than work-related frameworks such as apprenticeships. However, even more important was the integrative role assigned to the VocEd sector, in response to the mass immigration of Oriental Jews (“Sephardim”), stemming from North Africa, the Middle East and Yemen .

At the outset of statehood, the educational attainment level of the Jewish population in Israel (mainly of European origin) was amongst the highest in the world, second only to the United States (Easterlin 1961). By and large, the traditional, high-standard academic secondary schools were not regarded as providing an appropriate framework for these youngsters of low educational ability socioeconomic status. The 
small Voced system was expanded to take on the integrative role for which academic schools, geared towards matriculation and university entry, were not fitted. The VoEed sector, the majority of whose pupils came from Sephardie backgrounds, thus became the dominant provider of workers for the skilled trades.

One result of the growth of vocational schooling in Israel was the development of fairly rigid tracking within the Jewish education sector, based on divisions between the academic, agricultural and VocEd school sub-sectors (Shavit 1989). Tracking was intensified by the development of three steams within the VocEd sector: a matriculation (bagrut) track (formally leading to possible entry to higher education but with much lower success rates than the academic schools), and two nonmatriculation tracks, a regular and practical track. Tracking based on type of curriculum, together with an over-representation of Sephardie youngsters in the largely non-university directed VocEd schools, has resulted in a form of social tracking at the secondary school level based on ethnic background. In Israel an influential opposition to vocational schooling has developed, based on the view that it denies social inclusion and integration and equality of opportunity for Sephardie youngsters who are concentrated in these schools. VocEd, which was developed as a major framework for the social and cultural integration of new immigrants, became to be seen as a major institutional barrier to social inclusion of the disadvantaged groups enrolled in the VocEd system. Against this view, our own research shows that, for those youngsters that do not move on to tertiary education, VocEd can provide a clear wage advantage, in relation to wages levels of comparable groups.

\section{Immigrants}

\section{Human Capital: Portability verses Transferability}

Historically, Jews living in the Diaspora (particularly in Europe) have often been subjected to social and economic discrimination, even leading to waves of violence against them, confiscation of assets and expulsion. They have also invested considerably in the acquisition of human capital. One explanation offered for these relatively high levels of educational investments lies in the greater portability of human capital as opposed to physical capital investments, representing a hedge 
against future hostile policies that may be forged against them (Brenner and Kiefer 1981).

Israel is largely an immigrant society and large numbers of migrants have arrived with substantial human capital assets. But migrants may find their accumulated human capital investments to be less portable in practice, if their acquired skills are not transferable, in the sense of being well matched with the needs of the Israeli labor market. Any such a lack of transferability of (otherwise portable) human capital assets may be expected to delay the process of social and economic absorption and extend the period of social exclusion of new immigrants. The more general are human capital investments, the more readily transferable are they likely to be across national labor markets.

Many immigrants arrive in Israel with VocEd qualifications. Do these vocational skills, acquired prior to migration, provide immigrants with a labor market advantage over those educated at general secondary schools, as is the case for their Israelieducated counterparts? If so, then possession of vocational skills would represent a powerful tool for successful integration into the labor market, high wages and rapid social inclusion, contingent on gaining employment in matched occupations. However, VocEd supplies fewer general labor market skills than does secondary academic schooling; it is likely to be less transferable across national labor markets than is academic education, thus extending the process of absorption and the period of social exclusion of immigrants with vocational schooling. The question at issue then, is whether immigrants arriving with VocEd qualifications are advantaged in the process of absorption or are placed at a disadvantage, in comparison with migrants who completed general secondary schooling.

We examine this issue by analyzing the wages of new immigrants who had completed either VocEd or academic secondary schooling prior to migration, using data drawn from the 1983 Census of Population, the most recent census for which relevant information is available. New immigrants are defined as those who had arrived in Israel in the previous decade (ie between 1972 and the date of the Census). Before turning to the statistical analysis, we put this analysis into context through a brief discussion of the main process (and waves) of immigration to Israel. 


\section{Immigration Flows to Israel}

In the fifty years since statehood, the Jewish population grew at an average annual rate of 4.1 percent with net migration accounting for about half of this population growth. Over this period, over two and a half million Jews immigrated to Israel while about half a million (past immigrants as well as native Jews) out-migrated. It is customary to identify four major periods of immigration into Israel, each with its own particular characteristics in term of immigrant size, motivation and composition; these are shown in Table 2.

Mass immigration, immediately following statehood, led to a doubling of the Jewish population in three years; as a result of this immigration, the population grew at an annual rate of some 23 percent. The first to arrive were Holocaust survivors from Europe; shortly afterwards they were joined by immigrants from Asian and North African countries, motivated by ideological reasons or because of feelings of insecurity in their mother countries. The proportions of immigration by continent were: 49 percent from Europe, 35.4 percent from Asia and 15 percent from Africa, with only about 0.6 percent from the Americas and Australasia. The basic ethnic composition of the Israeli population was set at this time, the two major ethnic groups being Westerners (Ashkanazim) - Jews stemming from European and American countries and Easterners (Sephardim), from Asian and African countries.

While the great majority of immigrants arrived with meager assets, there were marked differences between the two groups. The Sephardim were more traditional, had larger families, were less educated and had fewer market skills than the Ashkanazie immigrants. As we have noted, the massive development of the VocEd system in Israel was largely a response to the low levels of educational attainment of Sephardie immigrants.

Following mass migration, the pace of immigration fell dramatically after 1951. Yet population increased during the period until 1966 at the still very high annual rate of 3.5 percent (2.4 percentage points being the result of immigration). The migrant composition remained basically similar, most arriving from Central Europe (excluding the USSR) and from North Africa. The pattern of immigration was 
cyclical, with ups and downs reflecting socio-economic conditions in the country; in 1953 the migration balance was negative.

The third period of immigration, followed the Six Day War in 1967. It is of particular interest because it was during the middle part of this period that the migrants constituting the sample on which our empirical work is based, arrived in Israel. Levels of immigration fell; immigration resulted in less than a one percent annual increase in the population and the natural population increase exceeded immigration. The source of origin of this immigration and its socio-economic level were also very different from earlier periods. More than half came from Western countries - Australia, North America, Latin America and South Africa - and, for the first time, a sizeable immigration came from the USSR. Immigrants from Asia and North Africa were of a higher socio-economic level than those who came in earlier periods. Overall, the immigrants who arrived in this period came equipped with higher educational attainments, technological skills and human capital investments than in earlier periods.

The fourth period, characterized by a massive and continuing influx of Soviet immigrants, begins in 1989 with the dramatic increase in immigration triggered by Glasnost and in response to worsening political and economic conditions in the former USSR. This was accompanied by an increase in the flow of Ethiopian immigrants that had begun towards the end of the previous period. In contrast to the relatively high level of education and skills of Soviet immigrants, the relatively small Ethiopian immigration is characterized by very limited educational resources (Neuman, 2000).

\section{Benefits of Foreign VocEd in the Israeli Labor Market.}

Against this background, we now examine how well recent immigrants, who had terminated education at the secondary level, fared in the labor market. Do immigrants arriving with VocEd qualifications have an advantage over those who had studied at general secondary schools? Is VocEd matching important, as was found in our previous research on the non-immigrant population as a whole? In that previous research we showed that VocEd completers who worked in occupations related to 
their courses of vocational study ('matched' occupations) earned over eight percent more than either VocEd workers not working in matched occupations or than those who had attended general secondary education. We replicate this work using a sample of immigrants who had arrived within the last ten years; we compare the results with those for veteran Israelis.

\section{$\underline{\text { Model and data }}$}

The model used is as follows (see Neuman and Ziderman 1999 for a fuller specification):

Ln $($ Hourly Wage Rate $)=a^{\prime} X+b$ VOC $+c$ ROCC + d VOCM.ROCC $+u$,

where VOC relates to all those who had taken VocEd courses at secondary school (academic schooling in the constant term) and ROCC (VocEd-related occupations) comprises those occupations for which relevant VocEd courses are available. The term VOCM.ROCC comprises those VocEd completers who are employed in VocEdrelated courses that are matched with the actual courses of VocEd that they studied. ${ }^{3}$

$\mathrm{X}$ is a vector of the following additional explanatory variables:

\section{Schooling variables}

Years of schooling (ranging from 9 to 13 years) $-\mathrm{SCH}$

Dummy variables relating to the highest level of schooling certification attained - completed secondary school, and gained bagrut (matriculation) -S.CERT and BAG, respectively. The category "no certificate obtained" enters the constant term.

\section{Ethnic background variable}

A dummy variable indicating ethnic origin $($ Sephardie $=1$.

Ashkenazie $=0)$ - ETHNIC 


\section{Work-related variables}

Years of work experience, defined as Age - $\mathrm{SCH}-6$ (EXP)

EXP squared

Log of number of weeks worked in the past year (WEEKS)

Dummy variables relating to sector in which employed (Agriculture in the constant term)

Dummy variables relating to occupation (Agricultural workers in the constant term)

$\mathrm{EXP} * \mathrm{SCH}$

As in our previous work, the data set used was the 20 percent sub-sample of the 1983 Israeli Census of Population and Housing. Restricting the sample to males aged 2549 , information relating to the variables listed above was drawn for two groups, new immigrants and veterans. ${ }^{4}$ The immigrant category comprises individuals who had arrived within the last ten years and who had attended secondary education in the country of origin. Veterans are defined as Israeli born or immigrants who have been in the county in excess of a decade and attended secondary school in Israel. In all, the sample consisted of 796 immigrants and 14,566 veterans.

For the total sample, for all of whom education terminated at the secondary school level, information was available on type of education received: vocational or academic. The Census identified fields of VocEd study, information that is lacking in the latest Census for 1995. Occupational codes at the two digit level were compared with the eight VocEd fields, to identify ROCC (VocEd-related occupations). For example, the occupational category "Electrician/Electronic Fitters" is regarded as related to the VocEd course of study "Electricity" and is defined as a relatedoccupation (ROCC). If a worker who had studied VocEd was employed in an occupation that was matched to his course of VocEd study, then he was included in the category VOCM.ROCC. ${ }^{5}$ 
$\underline{\text { Results }}$

The average hourly wage of veterans (18.22 shekels) exceeded that of the immigrant group (15.16 shekels); there were no striking differences between the two groups in the work-related exogenous variables. Half of the immigrant group arrived with a matriculation certificate, compared with only 13 percent for the veteran population. While 71 percent of the veteran sample had attended vocational school, only 38 percent of immigrants had done so. Against this, there is a striking difference between immigrant and veteran groups in the percentage of VocEd graduates employed in matched occupations: 52 percent for immigrants as opposed to 37 percent for veterans.

Separate regressions were run for the immigrants and veterans. Summary results for the key variables in the two regressions are shown in Table 3. The results for the veteran group parallel those found in our earlier work. Workers who had taken VocEd courses receive wages not significantly different from those who attended academic schools. Employment in ROCC offers a small wage advantage (significant at $=0.079$ ). However, those workers who took VocEd courses and are employed in related occupations (VOCM.ROCC) receive a wage premium of 7.9 percent (coefficient of 0.075). ${ }^{6}$ For the immigrant sample, none of the three key variables are significant; in particular, workers with a VocEd background and employed in a matched occupation, enjoy no wages advantage over other groups. ${ }^{7}$

We added an additional explanatory variable to the regression, LEN - length of time that the immigrant is in the country; the coefficient was positive and significant $(0.015, \mathrm{t}=2.01)$, indicating that hourly wages rise by 1.5 percent for each year since immigration. Immigrants evidently benefit from a process of improvement in the labor market, as they integrate more successfully over time. However, none of a series of defined interaction variables between LEN and the various other variables (such as $\mathrm{SCH}, \mathrm{EXP}$ and type of schooling certificate, including VOCM.ROCC), were significant - an indication that this improvement factor is constant for all groups. Over the longer term, as expected, this improvement factor related to length of time since arrival, falls away; it was insignificant in the regression for veterans. 
Overall, based on Table 3, we observe a very different pattern for the two groups. For the veteran population who did not pursue full-time schooling beyond secondary school, the majority (some 70 percent) attended VocEd schools, but less than 40 percent worked in occupations related to VocEd courses studied. Those who did so, enjoyed wage premiums of 8-9 percent. The parallel group of new immigrants displays a smaller percentage of workers who attended VocEd schooling; however, for those who did so, well over half worked in matched occupations. But matching does not offer any wage advantage to immigrant workers.

Why do immigrant workers differ from veterans in terms of the efficacy of matching? The most likely explanation seems to lie in terms of the poor transferability of VocEd skills across national labor markets, an issue discussed above. Thus immigrants, formally defined as working in matched occupations (i.e. those included in the VOCM.ROCC category), in reality are matched only imperfectly. This stems from a lack of conformity between the VocEd schooling system abroad (in the countries of out-migration) and the more specific needs of particular occupational labor markets in Israel, which are better served by VocEd courses provided here. VocEd received abroad, even when used here in fields that seem formally appropriate to the VocEd courses studied, does not offer any labor market advantage to immigrants, because of its limited transferability. ${ }^{8}$ The regression results suggest that an appropriate policy for improving wage levels of immigrants with VocEd backgrounds would be the provision of special training programmes aimed at updating immigrants' VocEd skills and bringing them closer into conformity with the needs of particular skilled labor markets.

\section{Sephardim}

\section{Sephardie Participation in VocEd}

We have noted the central role assigned to the VocEd sector in the integration of youngsters from the Eastern countries of North-Africa, the Middle East and Yemen into the Israeli educational system. These Sephardie youngsters came from a lowsocioeconomic background and had lower educational ability than those whose origins were from the European-American Western countries. 
Table 4 shows that the majority of individuals who had studied in the VocEd sector came from Sephardie backgrounds. The data in the table, drawn from the 1983 Census of Population, are based on two questions addressed to the 20 percent sample: what was the last school attended and what was the highest certificate received? Responses to these two questions provide accumulated data for all respondents and make possible the derivation of estimates for the whole population aged 15 and above, at the time of the census. Over one quarter of Sephardie Jews reported that the last school attended was secondary vocational, compared to 17 percent of Ashkenazim (Western Israelis). The share of VocEd school attenders who received the matriculation certificate is higher among Westerners, indicating higher educational attainments. While the share of Western men in the population of age 15+ is larger (54 percent for Westerners as against 46 percent for Easterners), the relative share of pupils of Sephardie background in VocEd is larger (57 percent).

The table clearly shows the educational attainments of Sephardie Jews to be lower than those of Westerers. A lower percentage of the Sephardie population students have bagrut; this is true both for those who attended VocEd schools and for those who studied at academic secondary schools. Most striking is the difference in university enrollment - 19 percent of the Western adult population and only 4.6 percent of Sephardim have at least a partial university education. Moreover, graduation rates are also significantly higher for Westerners.

\section{Wage Benefits of VocEd}

The Sephardie majority of VocEd present and past students have lower educational attainments than Westerners. However, Sephardie VocEd students seem to benefit more from the VocEd system than do Westerners. This is the central finding of a comparison of the wage outcomes of VocEd for Sephardie and Ashkenazie workers. Using the model employed in the preceding section, separate regressions were run for Sephardie and Ashkenzie workers. Regression results in Table 5 show that Sephardie workers who had studied in the VocEd system and are employed in matched occupations, enjoy a wage premium of 10.9 percent over non-matched workers (coefficient of 0.104 ). This is significantly higher than the wage premium of 8.1 percent (coefficient of 0.078) received by matched VocEd workers of Western 
origin. ${ }^{9}$ In addition, Sephardie workers (but not Westerners) employed in VOCrelated occupations receive an extra 5.3 percent on their hourly wage. These two advantages almost cancel out the overall wage differential that Westerners receive (18.04 shekel per hour, compared with 14.87 shekel for Sephardie workers). Thus the VocEd schooling system, which was designed primarily to help integrate Sephardie youth into the educational system, also plays an important role in integration into the labor market.

\section{Israeli Arabs}

Arab and Jewish education at the primary and secondary levels are separated in the Israeli educational system, into distinct Arab and Jewish sectors. ${ }^{10}$ A major difference between the two sectors lies in the very different approaches accorded to the development of vocational schooling. VocEd institutions were developed rapidly in the Jewish sector in the early years of statehood, largely in response to the mass Sephardie immigration. The lack of a parallel development of VocEd in the Arab sector is to be explained both by the absence of such a challenge to the system as well as by its more traditional ethos. In contrast to the dual, multi-tracked Jewish secondary sector (VocEd itself offers various tracks, some leading to the bagrut (matriculation), others are non-matriculation, more practical, tracks), Arab secondary education is primarily single tracked and academic in orientation. Thus whereas the Jewish secondary sector offers a range of educational alternatives, aimed at youth with differing abilities and aspirations, the Arab sector is more narrowly focussed, concentrating on the traditional preparation for the bagrut examinations and entry to higher education.

Comparisons between the Jewish and Arab sectors illustrate the relative paucity of VocEd provision in the Arab sector. Participation in general secondary schooling (per thousand population aged 14-17) in the Arab sector was 369 in 1997, close to the comparable figure for the Jewish sector (401). However, striking differences between the two sectors are evident for VocEd: 140 per thousand population aged 14-17 for the Arab sector, as against 347 for the Jewish sector; relative enrollment in the Jewish sector is about two and a half times greater. In 1997, the ratio of vocational school to 
academic school enrollment in the Arab sector was 0.37 , compared with 0.87 for the Jewish sector.

Parallel differences between Jews and Arabs are to be seen in comparative statistics for the population as a whole, drawn from the 1983 Census of Population (Table 6). In terms of the last school attended (i.e. those who terminated schooling at the secondary level), 14-19 percent of both Arabs and Jews in the population aged 15+ had attended an academic school. In contrast, over twenty percent of Jews had attended VocEd, compared with only 4 percent for the Arab population.

The concentration of the Arab sector on a traditional academic curriculum for secondary education, may be seen as advantageous to the Arab community. The Arab secondary school system is not subject to much of the criticism aimed at the Jewish tracked system, in terms of lack of opportunities for upward educational and social mobility for disadvantaged youngsters in the less prestigious tracks. In reality, the lack of development of VocEd in the Arab sector and its concentration on academic education probably results in a double disadvantage for Arab youngsters.

On the one hand, the lack of a well developed VocEd system would appear to deny the less academically oriented Arab youngsters the possibilities of getting into good class employment, through completing vocational school and subsequently working in a matched occupation. We cannot be certain of this, however, because we were unable to run the regression model specified above for the Arab minority, due to insufficient observations of Arab workers in our sample. On the other hand, the achievements of Arab academic schools, formally aimed at matriculation (the gateway to higher education) have not been high. The percentage of Arabs in the 17-year age group gaining a matriculation certificate (the age of final year secondary schooling) has grown more rapidly than that for Jews over recent years, but remains less than half the Jewish rate. In terms of university education, Arabs constitute only 5 per cent of the student population but some 14 percent of the relevant age group. In terms of the total population, 12 percent of Jews achieved university education compared with only 4 percent for Arabs.

Overall, the limited coverage of VocEd and the relatively low achievements of academic schools in the Arab sector means that large numbers of Arab youngsters are 
not able to benefit from the potential wage advantages from studying in the VocEd system and working in a matched occupation. Yet few are able to achieve upward mobility through success in the dominant academic schooling sector, leading onto higher education. They fall between two stools.

\section{Women}

\section{Female Participation in VocEd}

Female participation at secondary schooling overall is only slightly higher for girls than for boys. In 1997 the participation rate for girls was 780 per thousand female population aged 14-17, compared with 717 for boys. However significant differences are evident in enrollment rates by type of school. For boys, the ratio of students enrolled in VocEd schools to academic schools is 1.07, while for girls the ratio drops to 0.70 ; relative enrollment for boys is about 50 percent greater (Annual Statistical Abstract 1998). There is a trend of decrease in the gender difference. In 1983 the respective ratios for boys and for girls were 1.42 and 0.77 - relative enrollment for boys was almost twice that of girls.

An examination of accumulated data based on last school attended and highest certificate received provides similar information (Table 7). A larger percentage of men than women terminated secondary education at a vocational school -25 percent for men and 17 percent for women (aged 15+ in 1983). The opposite is the case for academic secondary schooling - 16 percent for men against 22 percent of women. The percentage of students who graduated with a matriculation certificate is similar for boys and girls: approximately, 11 percent for those who had attended VocEd schools and around one third for their academic school counterparts.

Table 8 provides information on the differences in the distribution of VocEd field of study between males and females. About two thirds of women had studied clerical, secretarial and bookkeeping subjects and 25 percent had taken sewing and fashion; only 3.5 percent of men chose these fields of study. Against this, the great majority of men had studied metal work (44 percent), auto mechanics (20 percent) and electricity (14 percent). Very few women had enrolled in these fields (less than one percent in 
all three). This very different distribution of VocEd courses of study by gender greatly influences the occupational distribution for full-time working men and women in the sample About half of the 14,049 men were skilled workers while 67 percent of the 7,605 women were clerical workers.

This raises the question: why do women not enter the more prestigious technical fields of study but rather gravitate towards clerical courses and sewing? Social discrimination and exclusion is most probably responsible for this phenomenon. Sewing and clerical jobs are traditionally female jobs, while men are commonly believed to have better technical and manual skills.

\section{Female-Male Wage Differentials}

Another major difference between the genders, probably related to the former one, is between wage levels. The male average hourly wage rate is close to 30 percent higher than the female wage rate. The difference between monthly earnings is even larger (54 percent) due to longer working hours for men (50 hours per week, compared to 43 hours per week for women). The hourly wage differential cannot be explained entirely by differences in education, years of experience or ethnic origin. Women are more educated - 24 percent possess a matriculation certificate compared to 13 percent for men - and are only slightly less experienced (an average difference of one year).

Gender wage differentials in the Israeli labor market are well documented and it is known that in Israel, as in other countries, more than 50 percent of the wage difference stems from wage discrimination (e.g., Neuman and Oaxaca, 1998). However, the issue, whether women, as men, benefit from VocWEd schooling, has not been examined. Does VocEd improve the labor force performance of women who are employed in VocEd matched occupations, as was found for males in our previous research? Or do they differ from men in this area too, and thus may be seen as another component of wage discrimination.

The probe this issue, we repeat the wage regression analysis outlined above, comparing outcomes for women with those for men. Table 9 shows summary results for the three key variables, VOC, ROCC and VOCM.ROCC. While men who 
attended vocational schools and work in matched occupations enjoy a wage premium of 9.85 percent (coefficient of 0.094 for VOCM.ROCC), women working in matched occupations do not receive any wage advantage. Moreover, men who work in VocEd related occupations (ROCC) have an additional premium of 4.1 percent. Women in these occupations also seem to receive a wage premium (of about 5.5 percent) but this is significant only at an 8 percent significance level $(\mathrm{t}=1.77)$. A closer and more detailed investigation (not reported here but available from the authors) shows that a wage advantage for women working in ROCC is found only for women employed in technical occupations, where women are to be found in only very small numbers. In these occupations they receive a 20 percent wage premium. For women employed in VocEd related clerical and business occupations, there is an hourly wage disadvantage of about 7 percent. Finally, women who studied at vocational schools (VOC) earn less than their counterparts who attended academic schools (by about 4.8 percent). This might reflect an ability or selectivity bias, with the more able girls enrolling in academic schools.

These empirical findings combined, lead to the conclusion that women are excluded from the potential wage advantages of study at vocational schools. This results from their inability (because of social norms) or their unwillingness to choose the appropriate fields of VocEd study. They concentrate in the business subject courses (clerical and sewing) instead of moving towards the more profitable technical fields. One possible remedy, in concert with other measures, would be to offer better career guidance, encouraging them to move into technical courses of study. ${ }^{11}$

\section{Conclusions and a Caveat}

A large empirical literature has shown that in many countries, particularly developing countries with high open and disguised unemployment, low employment growth and labor market distortions, vocational schooling has not proved to be a successful vehicle for enhancing the economic welfare of minorities and disadvantaged groups. In other countries, characterized by a more permissive economic environment, vocational schooling has resulted in improved labor market performance when VocEd graduates find employment in matched jobs, ie jobs related to the courses studied. 
Israel is a case in point. Previous research by the present authors has shown that VocEd in Israel has led to successful labor market outcomes, in terms of augmented wages for male VocEd graduates who work in course-related jobs. But this research, in common with findings for other countries, relates to VocEd graduates generally. As such, the research may not be very revealing for policy makers intent on addressing such issues as improving the economic wellbeing of particular minorities and disadvantaged groups. Four such sub-groups of the working population are of particular concern, because of barriers to their full integration into the labor market; these are: new immigrants, sephardie Jews, Arabs and women. In this paper, we have examined the impact of VocEd on the wages of these four groups. Our findings differ from group to group, thus justifying our approach of examining the impact of VocEd on finer breakdowns of the population of secondary school completers.

New immigrants to Israel with VocEd secondary schooling qualifications, who arrived during the period 1972-1983, receive no labor market advantage from VocEd, compared with their peers who had studied at general secondary schools. No doubt their imported vocational skills match poorly with the needs of the Israeli labor market, because of low skills transferability across labor markets. It would seem that the provision of special training programs aimed at updating skills and bringing them into closer conformity with local labor market needs would constitute an appropriate policy for improving the wage levels of this group.

We were unable to examine statistically the effect of VocEd on the wages of Israeli Arabs because of the low number of observations in our sample. However, few Arabs have been able to benefit from the potential benefits to be derived from VocEd because of the relatively small size of the network of Arab vocational secondary schools in Israel (about half that of the Jewish sector). Moreover, student performance in Arab academic secondary schools is not high. The desirability of a significant extension of the Arab VocEd system seems to be indicated, in parallel with better resourcing of Arab academic secondary schools. 
Sephardie Jews constitute the only group of the four examined to derive significant benefits from VocEd schooling; they receive a wage advantage of over $10 \%$ if employed in matched occupations, compared with a wage premium of $8.1 \%$ for Western Jews.

Women, at present, do not gain greatly from VocEd. As is the case with vocational schooling in many other countries, relatively few women enroll in courses leading to the high-paying blue collar occupations typically held by men; they are overrepresented in so-called "female" VocEd courses which do not enhance earnings. One policy recommendation is the offering of better career guidance, encouraging female youngsters to enroll in technical, rather than clerical and sewing, VocEd courses of study. But such measures are likely to be effective only if introduced in parallel with other steps which, over the longer term, would lead to changes in social norms concerning appropriate subjects of study (and occupations) for women.

Findings for the four groups are summarized in Table 10.

We conclude with a caveat. Our results, based on data from the penultimate Census, relate to 1983; appropriate data were not available from the most recent Census in 1995. But in the interim changes have occurred in the objectives and curricular of vocational schools in Israel, in the direction of providing a richer program of technological education and less emphasis on practical skills. Renamed "technological schools", they are placing more emphasis on increasing the number of students who reach bagrut (and able to go on to post-secondary education) and on drastically reducing the workshop element in the curriculum. These reforms of the VocEd system as a whole, which are being introduced at a slow pace because of resource constraints and the lack of fore-planning, are timely. Increasingly, Israeli industry is calling for more broadly trained youngsters, preferably with bagrut, rather than more narrowly trained worker in specific skills; these can be provided on-the-job.

However, these planned reforms towards technological education, which are still very far from full implementation, do not answer the needs of all students. Particularly, academically-weaker youngsters from disadvantaged backgrounds are likely to be less well provided for in this new learning environment. On the one hand they will 
experience considerable difficulties in achieving a satisfactory bagrut; on the other hand, a drastic cut in the provision of practical, workshop training will deny them the opportunity of achieving the skills of trained workers while at secondary school. No plans are in place to complement the more "academic" VocEd curriculum with opportunities to receive practical training on-the-job, as found in many other countries. Thus the efficacy of the policies suggested above will be very much dependent on the speed with which the implementation of planned reforms is accelerated and the extent to which alternative provisions for practical training are made available. 
TABLE 1

General, Vocational and Agricultural Secondary Schooling in Israel Number of Schools and Enrollments

\begin{tabular}{|c|c|c|c|c|c|c|}
\hline \multirow{2}{*}{ Year } & \multicolumn{3}{|c|}{ Number of Schools } & \multicolumn{3}{c|}{ Enrollments } \\
\cline { 2 - 7 } & General & Vocational & Agricultural & General & Vocational & Agricultural \\
\hline & & & & & & \\
$1948 / 49$ & 39 & 26 & - & 7,168 & 2,002 & - \\
$1959 / 60$ & 113 & 60 & 30 & 32,894 & 10,167 & 5,016 \\
$1969 / 70$ & 219 & 258 & 30 & 63,731 & 49,556 & 7,641 \\
$1979 / 80$ & 231 & 310 & 27 & 61,581 & 70,681 & 5,108 \\
$1989 / 90$ & 340 & 314 & 24 & 95,723 & 97,799 & 4,718 \\
$1997 / 98$ & 472 & 315 & 23 & 127,842 & 100,260 & 6,133 \\
& & & & & & \\
\hline
\end{tabular}

Source: Annual Statistical Abstracts, various issues.

TABLE 2

Waves of Jewish Immigration: 1948-1998

\begin{tabular}{|l|l|l|l|c|}
\hline Period & $\begin{array}{l}\text { Jewish } \\
\text { Population at the } \\
\text { beginning of } \\
\text { period }\end{array}$ & $\begin{array}{l}\text { Number of } \\
\text { Jewish } \\
\text { immigrants }\end{array}$ & $\begin{array}{l}\text { Average Number } \\
\text { of immigrants } \\
\text { per year }\end{array}$ & $\begin{array}{l}\text { Annual population } \\
\text { growth rate } \\
\text { stemming from } \\
\text { immigration only }\end{array}$ \\
\hline $15 / 5 / 1948-1951$ & 649,500 & 687,624 & 194,244 & 22.6 \\
$1952-1966$ & $1,404,400$ & 587,472 & 39,165 & 2.4 \\
$1967-1989$ & $2,344,900$ & 558,909 & 24,300 & 0.9 \\
$1990-1998$ & $3,717,100$ & 879,486 & 97,721 & 2.4 \\
\hline
\end{tabular}

Source: Neuman (2000). 
TABLE 3

Regression Estimates of the Effects of Vocational Education and VocEd-Related Occupation on Male Hourly Wage Rate: Immigrants and Veterans

Census of Population and Housing, 1983

\begin{tabular}{|l|c|c|c|c|}
\hline \multirow{2}{*}{$\begin{array}{c}\text { Independent } \\
\text { variables }\end{array}$} & \multicolumn{2}{|c|}{ Veterans } & \multicolumn{2}{c|}{ Immigrants } \\
\cline { 2 - 5 } VOC & Coefficient & t-statistic & Coefficient & t-statistic \\
ROCC & 0.007 & 0.58 & 0.072 & 1.18 \\
VOCM.ROCC & 0.028 & 1.75 & 0.031 & 0.48 \\
& 0.075 & 4.88 & 0.054 & 0.69 \\
$\mathrm{R}^{2}$ & & & & - \\
$\mathrm{n}$ & 0.1781 & - & 0.2245 & - \\
\hline
\end{tabular}

Dependent variable: hourly wage rate $(\ln )$

For the full regression, see Appendix Table 1. 
TABLE 4

Last School Attended and Highest Certificate Received, Sephardie and Askenazie Jews Both Sexes

Census of Population and Housing, 1983

\begin{tabular}{||l|c|c|c|c|c|c||}
\hline \multirow{2}{*}{ Type of School } & \multicolumn{2}{|l|}{$\begin{array}{l}\text { Easterners } \\
\text { (Sephardie Jews) }\end{array}$} & \multicolumn{2}{l|}{$\begin{array}{l}\text { Westerners } \\
\text { (Askenazie Jews) }\end{array}$} & \multicolumn{2}{l||}{ Total - Jews } \\
\cline { 2 - 7 } & Number & Percentage & Number & Percentage & Number & Percentage \\
\hline $\begin{array}{l}\text { VocEd } \\
\text { of which: }\end{array}$ & 278,540 & 26.08 & 213,380 & 16.71 & 491,920 & 20.97 \\
$\begin{array}{l}\text { Matriculation } \\
\text { Certificate (bagrut) } \\
\text { High school certificate }\end{array}$ & 24,865 & 8.93 & 29,950 & 14.03 & 54,815 & 11.14 \\
\hline \hline $\begin{array}{l}\text { Academic secondary } \\
\text { of which: }\end{array}$ & 136,215 & 48.90 & 104,050 & 48.76 & 240,265 & 48.84 \\
$\begin{array}{l}\text { Matriculation } \\
\text { Certificate (bagrut) } \\
\text { High school certificate }\end{array}$ & 53,005 & 29.45 & 105,030 & 37.54 & 158,035 & 35.06 \\
\hline \hline $\begin{array}{l}\text { University } \\
\text { of which: }\end{array}$ & 56,150 & 31.19 & 91,535 & 32.71 & 147,685 & 32.76 \\
\hline $\begin{array}{l}\text { First degree } \\
\text { Higher degree }\end{array}$ & 48,790 & 4.57 & 240,025 & 18.79 & 288,815 & 12.31 \\
\hline \hline \begin{tabular}{l} 
Sotal population aged $15+$ \\
\hline \hline
\end{tabular} & 19,345 & 39.65 & 93,720 & 39.05 & 113,065 & 39.15 \\
\hline
\end{tabular}

Source: Israel, Central Bureau of Statistics (1987), Population and Localities 1983, Table 3, Jerusalem. 
TABLE 5

Regression Estimates of the Effects of Vocational Education and VocEd-Related Occupation on Male Hourly Wage Rate: Easterners and Westerners

Census of Population and Housing, 1983

\begin{tabular}{|l|c|c|c|c|}
\hline \multirow{2}{*}{$\begin{array}{c}\text { Independent } \\
\text { variables }\end{array}$} & \multicolumn{2}{|c|}{$\begin{array}{c}\text { Easterners } \\
\text { (Sephardie Jews) }\end{array}$} & \multicolumn{2}{c|}{$\begin{array}{c}\text { Westerners } \\
\text { (Askenazie Jews) }\end{array}$} \\
\cline { 2 - 5 } VOC & Coefficient & t-statistic & Coefficient & t-statistic \\
ROCC & -0.012 & 0.78 & -0.007 & 0.38 \\
VOCM.ROCC & 0.052 & 2.71 & 0.021 & 0.90 \\
& 0.104 & 5.73 & 0.078 & 3.44 \\
$\mathrm{R}^{2}$ & 0.1641 & - & 0.1931 & - \\
$\mathrm{n}$ & 8,000 & - & 6,049 & - \\
\hline
\end{tabular}

Dependent variable: hourly wage (ln)

For the full regression, see Appendix Table 2. 
TABLE 6

\section{Last School Attended and Highest Certificate Received Arabs and Jews, Both Sexes}

Census of Population and Housing, 1983

\begin{tabular}{|c|c|c|c|c|c|c|}
\hline \multirow{2}{*}{ Type of School } & \multicolumn{2}{|c|}{ Arabs } & \multicolumn{2}{|c|}{ Jews } & \multicolumn{2}{|c|}{ Total - Israelis } \\
\hline & $\begin{array}{l}\text { Numbers } \\
\end{array}$ & Percentage & Numbers & Percentage & Numbers & Percentage \\
\hline $\begin{array}{l}\text { VocEd } \\
\text { of which: }\end{array}$ & 14,920 & 4.02 & 491,920 & 20.97 & 506,840 & 18.66 \\
\hline $\begin{array}{l}\text { Matriculation } \\
\text { Certificate (bagrut) }\end{array}$ & 1,805 & 12.10 & 54,815 & 11.14 & 56,620 & 11.17 \\
\hline High school certificate & 5,470 & 36.66 & 240,265 & 48.84 & 245,735 & 48.48 \\
\hline $\begin{array}{l}\text { Academic secondary } \\
\text { of which: }\end{array}$ & 52,735 & 14.20 & 450,800 & 19.22 & 503,535 & 18.54 \\
\hline $\begin{array}{l}\text { Matriculation } \\
\text { Certificate (bagrut) }\end{array}$ & 15,275 & 28.96 & 158,035 & 35.06 & 173,310 & 34.42 \\
\hline High school certificate & 17,130 & 32.48 & 147,685 & 32.76 & 165,815 & 32.73 \\
\hline $\begin{array}{l}\text { University } \\
\text { of which: }\end{array}$ & 15,940 & 4.29 & 288,815 & 12.31 & 304,755 & 11.22 \\
\hline First degree & 6,510 & 40.84 & 113,065 & 39.15 & 119,575 & 39.24 \\
\hline Higher degree & 2,225 & 13.96 & 72,205 & 25.00 & 74,430 & 24.42 \\
\hline Total population aged $15+$ & \multicolumn{2}{|c|}{371,345} & \multicolumn{2}{|c|}{$2,345,240$} & \multicolumn{2}{|c|}{$2,716,585$} \\
\hline Share of group $(\%)$ & \multicolumn{2}{|c|}{13.67} & \multicolumn{2}{|c|}{86.33} & \multicolumn{2}{|c|}{100.00} \\
\hline
\end{tabular}

Source: Israel, Central Bureau of Statistics (1987), Population and Localities 1983, Table 3, Jerusalem. 
TABLE 7

Last School Attended and Highest Certificate Received, by Gender

Census of Population and Housing 1983

\begin{tabular}{||l|c|c|c|c|c|c||}
\hline \multicolumn{1}{|c|}{ Type of School } & \multicolumn{2}{|c|}{ Men } & \multicolumn{2}{c|}{ Women } & \multicolumn{2}{c||}{ Total } \\
\cline { 2 - 7 } & Number & Percentage & Number & Percentage & Number & Percentage \\
\hline $\begin{array}{l}\text { VocEd } \\
\text { of which: }\end{array}$ & 290,050 & 25.35 & 201,870 & 16,81 & 491,920 & 20.97 \\
$\begin{array}{l}\text { Matriculation certificate } \\
\text { (bagrut) }\end{array}$ & 31,915 & 11.00 & 22,900 & 11.34 & 54,815 & 11.14 \\
High school certificate & 139,410 & 48.06 & 100,855 & 49.96 & 240,265 & 48.84 \\
\hline \hline $\begin{array}{l}\text { Academic secondary } \\
\text { of which: }\end{array}$ & 183,870 & 16.07 & 266,930 & 22.22 & 450,800 & 19.22 \\
Matriculation \\
Certificate (bagrut)
\end{tabular}

Source: Israel, Central Bureau of Statistics (1987), Population and Localities 1983, Table 3, Jerusalem. 
TABLE 8

Fields of Study of Vocational School Attenders

Males and Females Aged 25-65

Census of Population and Housing, 1983

\begin{tabular}{|l|c|c|}
\hline \multicolumn{1}{|c|}{ Field of Study } & $\begin{array}{c}\text { Males } \\
\text { (percentages) }\end{array}$ & $\begin{array}{c}\text { Females } \\
\text { (percentages) }\end{array}$ \\
\hline Agriculture & 10.21 & 7.33 \\
Electricity & 13.99 & 0.17 \\
Electronics & 7.07 & 0.62 \\
Metal Work & 44.21 & 0.56 \\
Auto Mechanics & 20.02 & 0.30 \\
Clerical, Secretarial and Bookkeeping & 3.35 & 61.60 \\
Sewing and Fashion & 0.20 & 24.92 \\
Hotel Trades & 0.94 & 20.80 \\
Total: & 100.0 & 100.0 \\
\hline Sample sizes & $\mathbf{9 , 9 0 0}$ & $\mathbf{3 , 5 7 6}$ \\
\hline
\end{tabular}

TABLE 9

Regression Estimates of the Effects of Vocational Education and VocEd-Related Occupation on Hourly Wage Rate: Males and Females Census of Population and Housing, 1983

\begin{tabular}{|l|c|c|c|c|}
\hline \multirow{2}{*}{$\begin{array}{c}\text { Independent } \\
\text { variables }\end{array}$} & \multicolumn{2}{|c|}{ Males } & \multicolumn{2}{c|}{ Females } \\
\cline { 2 - 5 } VOC & Coefficient & t-statistic & Coefficient & t-statistic \\
ROCC & -0.005 & 0.46 & -0.047 & 2.74 \\
VOCM.ROCC & 0.041 & 2.75 & 0.050 & 1.77 \\
& 0.094 & 6.63 & 0.022 & 1.09 \\
$\mathrm{R}^{2}$ & & & & - \\
$\mathrm{n}$ & 0.1915 & - & 0.2364 & - \\
\hline
\end{tabular}

Dependent variable: hourly wage rate $(\ln )$

For the full regression, see Appendix Table 3. 
TABLE 10

Effect of Vocational Education on the Hourly Wage Rate

of Disadvantaged Groups

\begin{tabular}{|c|c|c|c|}
\hline Disadvantaged Group & Outcome & Explanation & Policy \\
\hline Immigrants & No benefit & $\begin{array}{l}\text { Market matching of } \\
\text { imported vocational skills is } \\
\text { low because of poor skills } \\
\text { transferability }\end{array}$ & $\begin{array}{l}\text { Special program } \\
\text { for updating skills }\end{array}$ \\
\hline Arabs & Limited & $\begin{array}{l}\text { Coverage of the Arab VocEd } \\
\text { sector is limited: only half } \\
\text { the size of the Jewish VocEd } \\
\text { sector. Few Arab youths can } \\
\text { gain potential benefits of } \\
\text { VocEd. }\end{array}$ & $\begin{array}{l}\text { Extension of the } \\
\text { Arab VocEd } \\
\text { school network }\end{array}$ \\
\hline Sephardim (Easterners) & Positive & $\begin{array}{l}\text { Jews of Eastern origin, who } \\
\text { took VocEd courses, receive } \\
\text { a wage advantage of } 10.9 \% \\
\text { if working in matched } \\
\text { occupations. The wage } \\
\text { premium for Western Jews } \\
\text { is } 8.1 \%\end{array}$ & - \\
\hline Women & No benefit & $\begin{array}{l}\text { Social norms lead to under- } \\
\text { representation of women in } \\
\text { those VocEd courses that } \\
\text { lead to high-paying blue } \\
\text { collar occupations: over- } \\
\text { representation in typically } \\
\text { female courses of VocEd }\end{array}$ & $\begin{array}{l}\text { Better course } \\
\text { guidance and } \\
\text { counselling }\end{array}$ \\
\hline
\end{tabular}




\section{APPENDIX TABLE 1}

Regressions of Hourly Wage Rates (In)

(Immigrant and veteran male salaried workers, general and vocational school attenders, 1983)

\begin{tabular}{|c|c|c|c|c|}
\hline \multirow{2}{*}{ Independent Variables } & \multicolumn{2}{|l|}{ Immigrants } & \multicolumn{2}{|l|}{ Veterans } \\
\hline & Coefficient & t-statistic & Coefficient & t-statistic \\
\hline YRS.SCH & 0.014 & 0.79 & 0018 & 125 \\
\hline EXP & 0.061 & 1.32 & 0.033 & 3.09 \\
\hline $\mathrm{EXP}^{2}$ & -0.0015 & 2.62 & -0.0007 & 6.25 \\
\hline EXP*YRS.SCH & 0.0002 & 0.07 & 0.001 & 1.59 \\
\hline WEEKS (ln) & -0.921 & 13.20 & -0.772 & 40.29 \\
\hline ETHNIC & -0.131 & 2.16 & -0.109 & 10.06 \\
\hline LEN & 0.015 & 2.08 & - & - \\
\hline Immigrated 1948-64 & - & - & -0.012 & 1.04 \\
\hline Immigrated 1965-71 & - & - & -0.035 & 1.15 \\
\hline \multicolumn{5}{|l|}{ Economic Sector } \\
\hline IND & -0.018 & 0.13 & 0.077 & 2.42 \\
\hline ELECT & 0.019 & 0.10 & 0.211 & 4.91 \\
\hline COMM & 0.011 & 0.07 & -0.032 & 0.93 \\
\hline FIN & 0.087 & 0.51 & 0.163 & 4.54 \\
\hline TRANS & -0.091 & 0.56 & 0.058 & 1.71 \\
\hline PUB & -0.081 & 0.55 & -0.028 & 0.85 \\
\hline PRIV & -0.148 & 0.86 & -0.042 & 1.08 \\
\hline CONST & -0.299 & 1.65 & -0.016 & 0.43 \\
\hline \multicolumn{5}{|l|}{ Occupation } \\
\hline ACAD & 0.483 & 1.07 & 0.350 & 4.34 \\
\hline TECH & 0.459 & 1.36 & 0.393 & 8.28 \\
\hline MANAG & 0.705 & 1.95 & 0.514 & 10.52 \\
\hline CLER & 0.185 & 0.56 & 0.230 & 5.01 \\
\hline SALES & 0.142 & 0.41 & 0.226 & 4.50 \\
\hline SERV & 0.081 & 0.24 & 0.226 & 4.57 \\
\hline UNSKILL & 0.157 & 0.46 & 0.114 & 2.05 \\
\hline SKILL & 0.233 & 0.71 & 0.180 & 4.02 \\
\hline \multicolumn{5}{|l|}{ Certification } \\
\hline S.CERT & -0.007 & 0.10 & 0.065 & 4.74 \\
\hline BAG & 0.078 & 1.07 & 0.108 & 5.24 \\
\hline VOC & 0.072 & 1.18 & -0.007 & 0.58 \\
\hline ROCC & 0.031 & 0.48 & 0.028 & 1.75 \\
\hline VOCM.ROCC & 0.054 & 0.69 & 0.075 & 4.88 \\
\hline Intercept & 4.849 & 5.57 & 4.603 & 23.69 \\
\hline $\mathrm{R}^{2}$ & 0.2245 & - & 0.1781 & - \\
\hline Sample size & 796 & - & 14,566 & - \\
\hline
\end{tabular}

Reference Groups: $\quad$ Economic Sector-Agriculture

Occupation- Agricultural workers

Period of immigration (for veterans) - before 1947 or Israeli born 
APPENDIX TABLE 2

Regressions of Hourly Wage Rates (In)

(Full time Easterner and Westerner salaried workers, general and vocational school attenders, 1983)

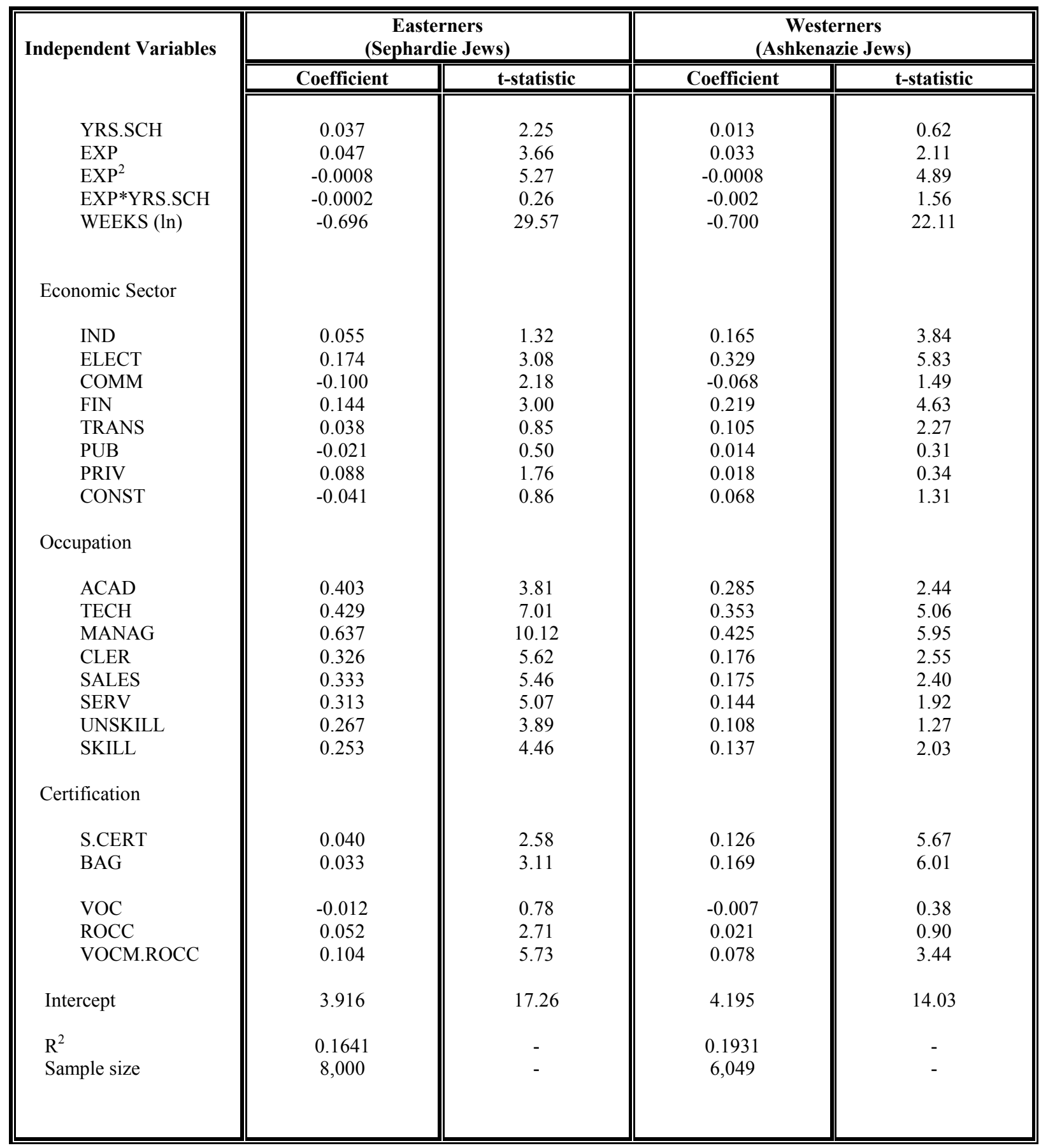

Reference Groups: Economic Sector-Agriculture

Occupation- Agricultural workers 


\section{APPENDIX TABLE 3}

Regressions of Hourly Wage Rates (In)

(Full-time, male and female salaried workers, general and vocational school attenders, 1983)

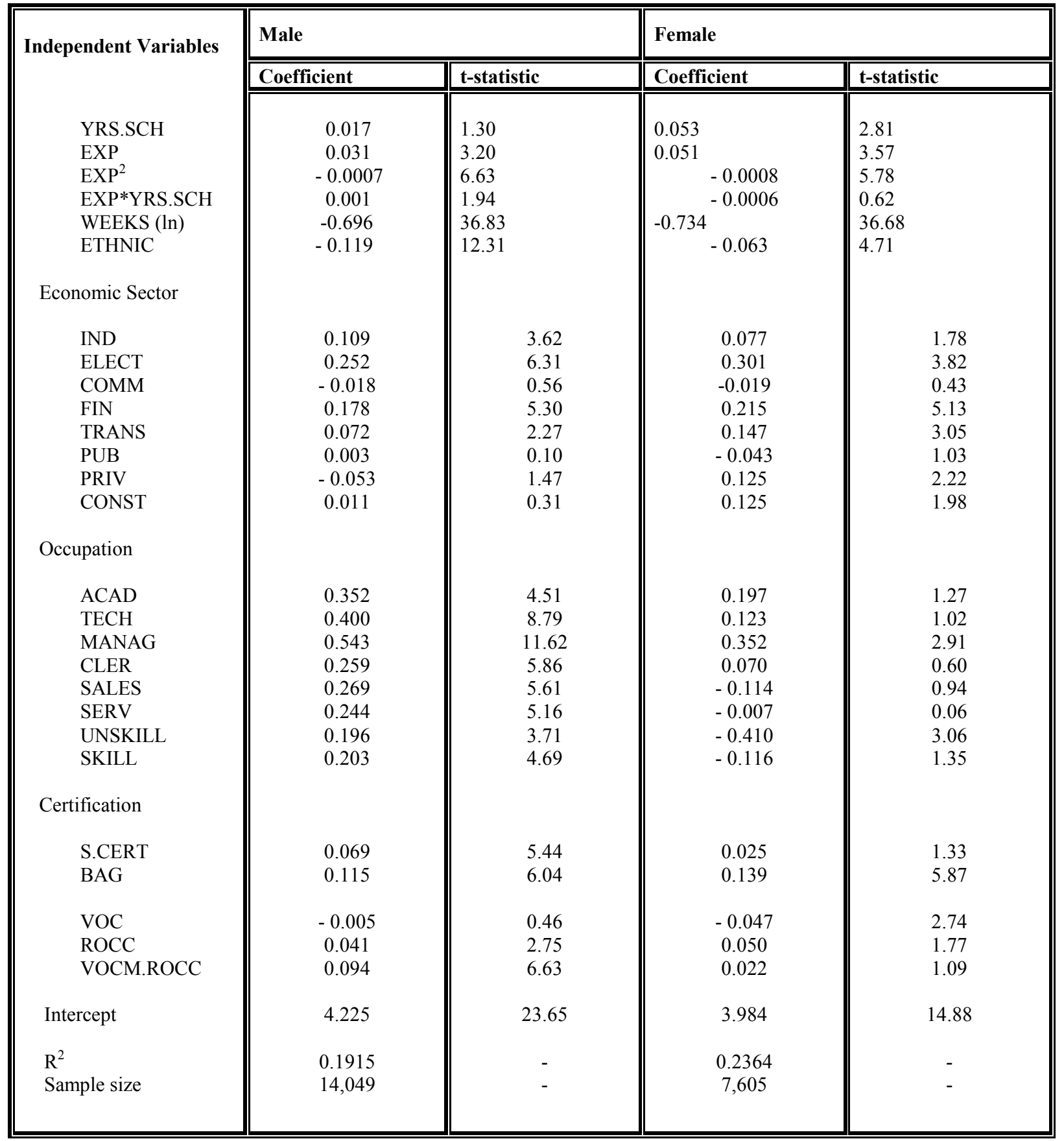

Reference Groups: $\quad$ Economic Sector-Agriculture

Occupation- Agricultural workers 


\section{References}

Arriagada, A-M. \& Ziderman, A. (1992), Vocational Secondary Schooling, Occupational Choice, and Earnings in Brazil, World Bank Policy Research Working Papers WPS 1037. Washington: The World Bank.

Betts, J. R. and M. Lofstrom (1998), The Educational Attainment of Immigrants: Trends and Implications, NBER, Working Paper 6757.

Bishop, J. (1989), Occupational Training in High School: When Does it Pay Off, Economics of Education Review, 8, pp. 1-15.

Brenner R. \& Kiefer, N.M, (1981), The Economics of the Diaspora: Discrimination and Occupational Structure, Economic Development and Cultural Change, 29(3), pp. 517-534.

Chung, Y-P. (1990), Educated Mis-employment in Hong Kong: Earnings Effects of Employment in Unmatched Fields of Work, Economics of Education Review, 9, pp. 343-350.

Easterlin, R.A. (1961), Israel's Development: Past Accomplishments and Future Problems, Quarterly Journal of Economics, 75(1), pp. 63-86.

Freidberg, R. (1995), You Can't Take it With You? Immigrant Assimilation and the Portability of Human Capital: Evidence From Israel, The Maurice Falk Institute for Economic Research in Israel, Discussion Paper \# 95-02.

Glasman, N.S. (1983), Israeli Political Roots and Effects of Two Educational Decisions, in: Politics and Education: Cases from Eleven Countries, ed., R. Murray Thomas, 191-210, Oxford: Pergamon Press.

Israel, Central Bureau of Statistics, Annual Statistical Abstract, various issues.

Israel, Central Bureau of Statistics (1987), Population and Localities 1983, Jerusalem.

Middleton, J., Ziderman, A. \& Adams, A.V. (1993), Skills for Productivity: Vocational Education and Training in Developing Countries. New York: Oxford University Press.

Min, W. \& Tsang, M.C. (1990), Vocational Education and Productivity: A Case Study of the Beijing General Auto Industry Company, Economics of Education Review, 9, pp. 351-364.

Neuman, S. (2000), "Aliya to Israel: Immigration under Conditions of Adversity," forthcoming in: Klaus Zimmerman (ed), European Migration: What Do We Know? Oxford University Press for CEPR.

Neuman, S \& Oaxaca, R.L. (1998), Estimating Labor Market Discrimination with Selectivity Corrected Wage Equations: Methodological Considerations and an Illustration from Israel, CEPR, Discussion Paper \#1915. 
Neuman, S. \& Ziderman, A. (1991), Vocational Schooling, Occupational Matching, and Labor Market Earnings in Israel, Journal of Human Resources, 26(2), pp. 256281.

Neuman, S. \& Ziderman, A. (1999), Vocational Schooling in Israel: Wage Effects of the VocEd-Occupation Match, Journal of Human Resources, 34(2), pp. 407-420.

Shavit, Y. (1989), Tracking and Educational Spiral: Arab and Jewish Patterns of Educational Expansion, Economics of Education Review, 33(2), pp. 216-231.

Tsang, M.C. (1997), The Cost of Vocational Training, International Journal of Manpower, 18, pp. 63-89. 


\section{Endnotes}

${ }^{1}$ These themes are developed more fully in Middleton et al (1993), chapter 2.

2 See Tsang (1997).

${ }^{3}$ It should be noted that the VOCM.ROCC term excludes those VocEd completers employed in ROCC that is not matched with the particular VocEd courses they studied.

${ }^{4}$ Women are discussed in Section 5.

${ }^{5}$ Other workers, say those that had studied in general secondary schools, might also be employed in ROCC; to do so, they will no doubt have picked up the requisite skills from training modes, other than VocEd, or informally on-the-job. Again, a worker who had taken VocEd, but was employed in a ROCC not related to his VocEd course of study, was not included in VOCM.ROCC.

${ }^{6}$ The coefficient gives an approximate rate of change. To calculate the exact rate one should use the formula $\mathrm{e}^{*}-1$ (where $*$ is the regression coefficient).

7 Since many immigrants work part time, a stage in the process of absorption into full-time employment, it was thought appropriate to include both full-time and part-time workers in both regressions. Our previous work used full-time workers only. Running the veteran regression, using fulltime workers only, gives broadly similar results: VOC remains insignificant $(-0.004, \mathrm{t}=0.36)$, ROCC is more strongly positive $(0.045, \mathrm{t}=2.29)$ and VOCM.ROCC is somewhat higher $\quad(0.090, \mathrm{t}=$ $6.35)$.

${ }^{8}$ Betts and Lofstrom (1998) who studied the educational attainments of immigrants in the US, found that American employers pay no premium to workers who have completed secondary schools abroad. A similar finding, that the origin of an individual's human capital is an important determent of its economic value, is also reported by Freidberg (1995). Using the same 1983 census she shows that education acquired abroad is significantly less valued in the Israeli labor market than education obtained domestically.

${ }^{9}$ The share of matched workers is similar for the two groups: 38.6 and 35.9 percent for Easterners and Westerners, respectively. The fields of study and occupational distributions also do not vary significantly.

${ }^{10}$ The Arab sector includes Moslem, Christian and Druze youngsters.

${ }^{11} \mathrm{We}$ assume that wage levels in the various occupations are exogenous and determined by factors other than sex. It might well be the case that occupational wages are affected by the sex composition too. In this case the entrance of women will lead to a decrease in wages. 


\section{IZA Discussion Papers}
No. Author(s)
270
B. Augurzky
C. M. Schmidt
271
B. Augurzky
C. M. Schmidt
272
C. Belzil
J. Hansen

273

G. Saint-Paul

274

P.J. Pedersen

N. Smith

275

G. S. Epstein

T. Lecker

276

277

B. Amable

D. Gatti

R. Winter-Ebmer

278

T. M. Andersen

279

T. M. Andersen

280

P. Apps

R. Rees

281

G. Saint-Paul

282
J. Albrecht
A. Björklund
S. Vroman

Title

Area

Date

The Evaluation of Community-Based

6

03/01

Interventions: A Monte Carlo Study

The Propensity Score: A Means to An End

6

$03 / 01$

Heterogeneous Returns to Human Capital and

5

03/01

Dynamic Self-Selection

Distribution and Growth in an Economy with

5

03/01

Limited Needs

Unemployment Traps: Do Financial Dis-

3

03/01 incentives Matter?

Multi-Generation Model of Immigrant Earnings:

1

03/01

Theory and Application

The Impact of Product Market Competition on

5

03/01

Employment and Wages

Evaluating an Innovative Redundancy-Retraining

6

03/01

Project: The Austrian Steel Foundation

Welfare Policies, Labour Taxation and Inter-

2

$04 / 01$

national Integration

Product Market Integration, Wage Dispersion

2

04/01 and Unemployment

7

04/01

the Life Cycle

5

04/01

Elites

Is There a Glass Ceiling in Sweden?

5

04/01 

and the Rising Returns to Skill: US and France 1964-2000 
298

P. Telhado Pereira

Returns to Education and Wage Equations
A. Stutzer

R. Lalive

301

J. R. Frick

G. G. Wagner

302

G. S. Epstein

A. Weiss
H. Bonin
G. Abío
E. Berenguer
J. Gil
C. Patxot 
Costs
A. Frederiksen
E. K. Graversen Germany:

Overtime Work, Dual Job Holding and Taxation 

2000 

A. lbourk
B. Maillard
S. Perelman
H. R. Sneessens

The Matching Efficiency of Regional Labour

Markets: A Stochastic Production Frontier

Estimation, France 1990-1995 